\title{
DEVELOPMENT AND IMPROVEMENTS OF COMPUTATIONAL METHODS IMPLEMENTED TO THE COLITEC SOFTWARE
}

\author{
S. V. Khlamov ${ }^{1,2}$, V. E. Savanevych ${ }^{3}$, O. B. Briukhovetskyi ${ }^{3}$, E. N. Dikov ${ }^{4}$, I. B. Vavilova ${ }^{2}$ \\ ${ }^{1}$ Institute of Astronomy, V. N. Karazin Kharkiv National University, \\ Kharkiv, Ukraine, sergii.khlamov@gmail.com \\ ${ }^{2}$ Main Astronomical Observatory, National Academy of Sciences of Ukraine, \\ Kyiv, Ukraine,irivav@mao.kiev.ua \\ ${ }^{3}$ Western Radio Technical Surveillance Center, National Space Agency of Ukraine, \\ Mukachevo,Ukraine,vadym@savanevych.com,izumsasha@gmail.com \\ ${ }^{4}$ Scientific Research, Design and Technology Institute of Micrographs, \\ Kharkiv, Ukraine, endikov@gmail.com
}

\begin{abstract}
The CoLiTec software is a large complex of processing modules that implements computational methods for the different purposes: brightness equalization of CCD-frames; automated calibration of the frames by bias-frame, dark-frame, and flat-field for reducing the dynamic range of brightness of the image background; frames track \& stack; automated rejection of the anomaly pixels; automated excluding of the objects with anomaly errors; determining the equatorial coordinates of the Solar System small bodies; accurate parameter's estimation of objects in frames; star's identification in the frames; astronegative plate's processing; ensemble differential photometry using comparison stars; determining the instrumental brightness of stars in CCD-frames; automated light curve creation; detection of very slow and very fast objects in series of CCD-frames; detection of objects with a near-zero apparent motion in series of CCD-frames.
\end{abstract}

The described methods work with the different forms of object images (point, long) and during the different observational conditions (with daily telescope guidance and without it). These methods lead to the increasing of astrometry and photometry accuracy indicators as well as the quality indicators for detection of the Solar System small bodies in series of CCD-frames.

The CoLiTec software is installed at several observatories of the world. In total, it was used for about 700000 observations and discovery of more than 1560 asteroids, including five NEO, four comets (C/2011 X1 (Elenin), $\mathrm{P} / 2011$ NO1 (Elenin), C/2012 S1 (ISON), and P/2013 V3 (Nevski)), 21 Trojan asteroids of Jupiter, and one Centaur.

The paper deals with the CoLiTec software 1) to process the different types of astroinformation, which can be fed on-line in different forms, for example, files stream and video stream, astroplates; 2) to decide the data saving problem at various servers and virtual observatories sites; 3 ) to improve computational methods and algorithms for automated detection of Solar System small objects; 4) to improve the accuracy of astrometry/photometry reduction.

Keywords: CCD, series of frames, observations, astrometry, photometry, computational methods, CoLiTec.
АБСТРАКТ. Програмне забезпечення CoLiTec - це потужний комплекс модулів обробки астрономічних даних, що реалізують обчислювальні методи вирівнювання яскравості ПЗЗ-кадрів; автоматичного калібрування кадрів за допомогою bias, dark та flat кадрів для зменшення динамічного діапазону яскравості фону зображення; складання кадрів; автоматичного виявлення аномальних пікселів; автоматичного виключення вимірювань положення об'єктів 3 аномальними помилками; точної оцінки положення об'єктів на кадрах; визначення екваторіальних координат малих об'єктів Сонячної системи; ототожнення зірок на кадрах та у каталогах, що застосовуються; обробка астронегативних платівок; високоточної фотометрії зір 3 використанням зір порівняння; визначення інструментальної яскравості зір на ПЗЗ-кадрах; автоматичної побудови кривих блиску зір; виявлення рухомих об'єктів 3 малою контрастністю зображень; виявлення дуже повільних і дуже швидких об'єктів на серії ПЗ3-кадрів; виявлення об'єктів з близьконульовим видимим рухом.

Обчислювальні методи працюють з різними формами зображень об'єктів (круговими, протяжними) і в різних умовах спостереження (з добовим веденням телескопа та без нього). Запропоновані та впроваджені методи призвели до покращення показників точності астрометрії та фотометрії, а також показників якості для виявлення малих тіл Сонячної системи на серії ПЗЗ-кадрів.

Програмне забезпечення CoLiTec широко використовується у різних обсерваторіях світу. Всього було виконано близько 700000 спостережень та відкрито більше 1560 астероїдів, у тому числі п'ять NEO, чотири комети (C/2011 X1 (Сленін), P/2011 NO1 (Сленін), C/2012 S1 (ISON) i P/2013 V3 (Невський)), 21 троянський астероїд Юпітера та один Кентавр.

У роботі розглядаються окремі аспекти програмного забезпечення CoLiTec, a самe 1) для обробки різних типів астроінформаційних даних; 2) для вирішення задачі збереження даних на різних серверах та сайтах віртуальних обсерваторій; 3) для вдосконалення об- 
числювальних методів та алгоритмів автоматичного виявлення малих об'єктів Сонячної системи; 4) для покращення астрометричної і фотометричної точності даних зображень на серії ПЗ3-кадрів.

Ключові слова: ПЗ3, серія кадрів, спостереження, астрометрія, фотометрія, обчислювальні методи, CoLiTec.

\section{Introduction}

At the present time the fast technological progress provokes creation of a big amount of the scientific information. There are a lot of different research fields in astronomy that use the high dimensional data sets for analysis. Some of them are as follows: variables stars, asteroids, comets, near-Earth objects, satellites and others.

What can we do with such a big data amount? We should develop and propose the automated software, likely the CoLiTec (Collection Light Technology) software, which is able to: 1) process this big amount of astroinformation; 2) discovery the new Solar System small objects in series of CCD-frames, including those that are the potential hazard near-Earth objects; 3 ) create the light curves of investigated variable stars, satellites, asteroids, etc. We have also the Data Mining problems with these big astronomical data sets. How can we solve them? We should develop the data pre-processing methods and data reduction models to simplify input data sets by reducing unnecessary information.

In this paper we describe the CoLiTec software accentuating on the following tasks: 1) to process the different types of astronomical information in automated mode, which can be fed on-line in various forms, for example, files stream and video stream, astroplates, 2) to decide the data saving problem at the different servers, virtual observatories sites. All these data can be obtained from the networks of automated ground-based and space-born observation systems or from the old astronomical plate's archives.

Authors have developed new and improved already existed methods for the full frames processing, including intraframe processing (parameter's estimation of all objects in the frames) and interframe processing such as parameters estimation of trajectories of all moving objects in the series of frames.

\section{CoLiTec software}

Software for automated processing of series of frames is necessary for the most effective astronomical observations. This possibility is provided by the CoLiTec software, http://www.neoastrosoft.com (Savanevych et al., 2012) that includes the following features:

- Automatic detection of faint moving objects $(\mathrm{SNR}>2.5)$;

- Working with a very wide field of view (up to $10 \mathrm{de}$ grees $\left.^{2}\right)$;

- FrameSmooth software for brightness equalization;

- Auto calibration and cosmetic correction;

- Fully automatic robust algorithm of astrometric reduction;

- Automatic rejection of the worst observations;
- Detection of very slow and very fast objects (from 0.7 to $40.0 \mathrm{pix}$./frame);

- LookSky - processing results viewer with userfriendly GUI;

- Multi-threaded support for multi-cores systems and local network;

- Processing pipeline managed by OLDAS (On-line Data Analysis System);

- CoLiTec Control Center (3C) with processing monitoring and logging.

These features allow effective using of CoLiTec software at the different observatories in the world.

The very brief sequence of the online processing is presented in Figure 1.

Images that are saved from the input telescopic devices are processed by the CoLiTec software in different modes. As a result, we can get necessary data such as light curves and appropriate reports. The more detailed process workflow of CoLiTec software is presented in Figure 2. The data control during processing is performed with using of the improved method, which is based on the subject mediator according to the UML-diagram (see Figure 3 ). The main advantage of this approach is the scalability of both the input and output interfaces of program modules in CoLiTec software.

The data mining is performed in OLDAS mode, which is especially significant. It allows us to conduct near realtime data processing and to assign confirmation of the most interesting objects at the night of their preliminary discovery (see Figure 4).
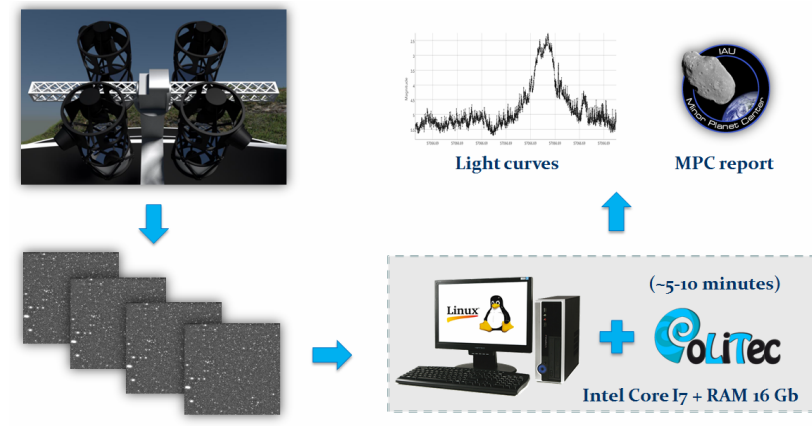

Figure 1: Brief sequence of the online processing by CoLiTec software

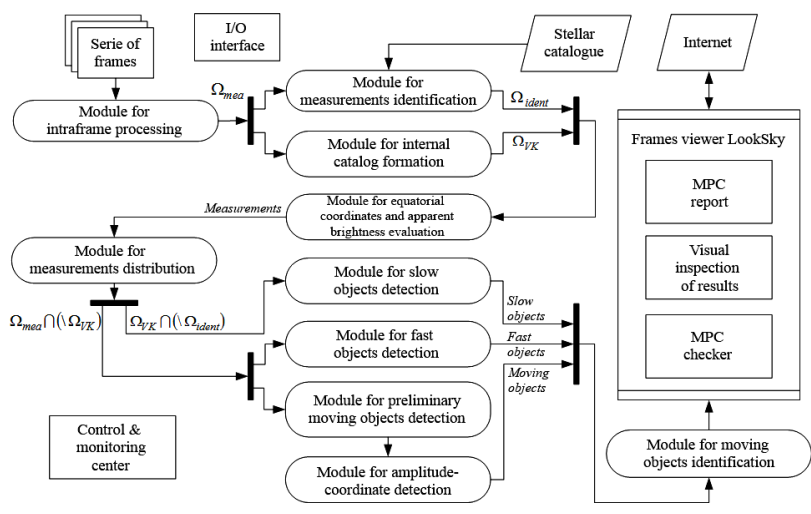

Figure 2: CoLiTec software process workflow 


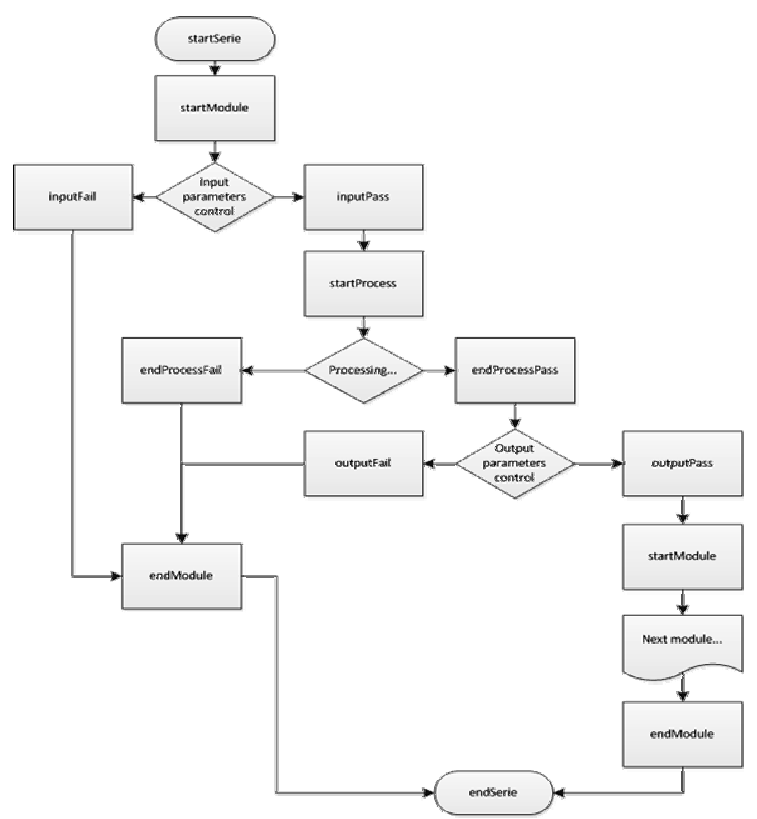

Figure 3: UML-diagram of the subject mediator

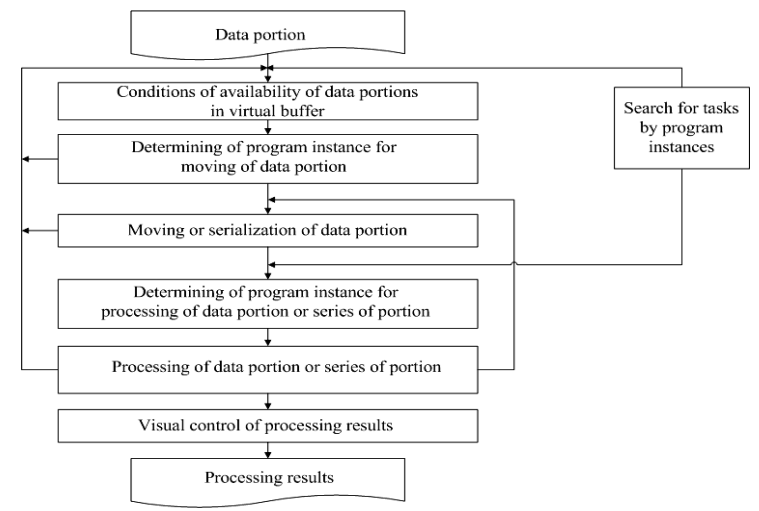

Figure 4: UML-diagram of OLDAS: determining the program instance for moving/processing of data portion

During the pre-processing step of CoLiTec software in OLDAS mode the all unsupported and corrupted frames will be rejected. The remaining useful information in the data set will be categorized into clusters with help of specified attributes. While processing pipeline starts receiving the classified FITS files, it identifies types of them (raw, master-frames, service raw frames - dark, flat, bias). And only after these actions the data is prepared for processing.

\section{Intraframe processing methods}

There are a lot of different types of telescope's aberration that can cause the corrupted astronomical data, for example, diffraction rays, motion blur, vignetting, flare light, coma and others.

The data with some aberrations is unnecessary information. So, the removing of it on the pre-processing stage allows increasing the quality of processing and reducing the execution time.

Also the pre-processing stage includes analysis of the input data and can make the decision about its quality.

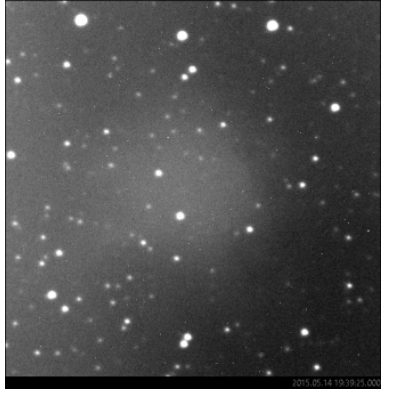

a)

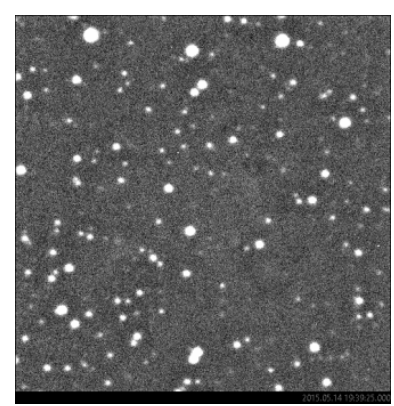

b)
Figure 5: a) raw image with flash, b) processing result

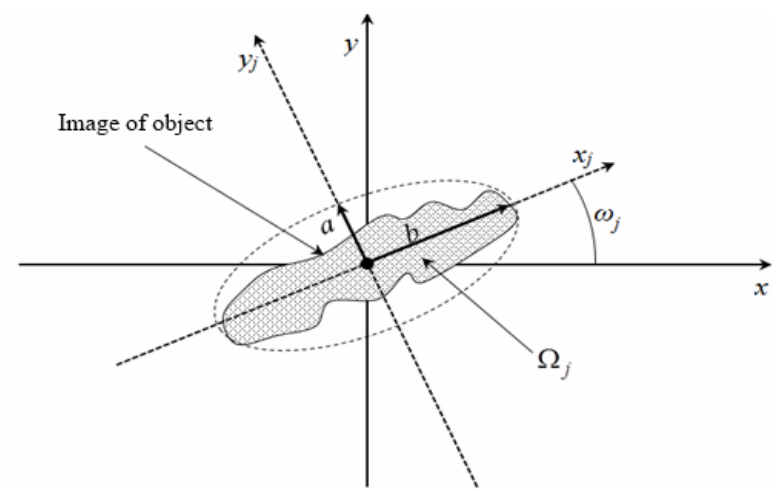

Figure 6: Selective signs for extended image of object

Some aberrations can be removed by developed special mathematical methods for frames filtration, brightness equalization and background alignment.

These methods allow processing the frames in the different frequency range. The real objects in frame are formed by high-frequency spectral components of the image. However, the frame background is the lowfrequency component. The subtraction of the lowfrequency background variations allows leaving the unchanged high-frequency components of the image.

The inverse median alignment is used in conjunction with calibration frames. It is especially important to use a master-dark frame. All master-frames are formed pixel by pixel. $10 \%$ of the largest and $10 \%$ of the smallest values of brightness of the each pixel is tentatively discarded (Dubovský et al., 2017).

In contrast to the flat-calibration of frames, inverse median filter removes coarse-grained components that are caused by the illumination from the Moon, the Sun, and illuminations of anthropogenic origin (Figure 5).

These methods lead to increasing of astrometry accuracy indicators and stars photometry quality as well as the quality indicators of asteroids and comets detection.

Also the CoLiTec software contains the improved matched filter, which is used for extended images of objects for CCD-frames taken without the diurnal tracking. It allows reconstructing the real images of extended objects. It is very helpful for working with frames with images of satellites, or for a malfunction of the diurnal tracking.

If all the objects in the frame are circular, and the object under investigation has an extended image, the detection method is based on the selective signs such as the eccentricity and the inclination (Figure 6). 


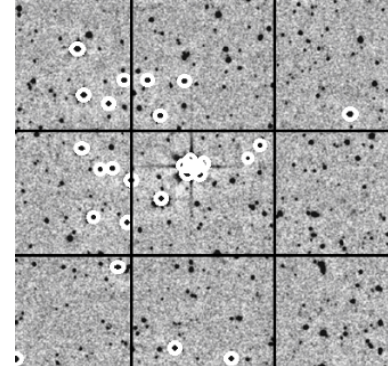

a)

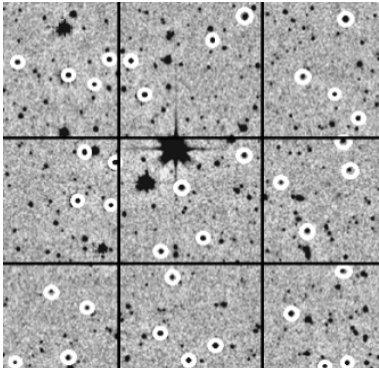

b)
Figure 7: a) positions of the brightest measurements in frame, b) uniform distribution of reference stars in frame

CoLiTec software allows performing of the astrometric and photometric reduction and detecting moving objects such as comets, asteroids or satellites in real time with the visual confirmation of processing results.

The full processing sequence of CoLiTec software includes intraframe and interframe processing stages.

During the astrometric reduction the recognizing of pixels that are related only to the real object's signal is performed. Then software removes all unnecessary pixels from the input data set to reduce amount of the measurements for processing.

After the estimation of the object's position the software starts the frames identification with the stellar catalogs (Akhmetov et al., 2017). This is a very difficult procedure because these catalogs contain more than billions objects with appropriate information about them including astrometric and photometric measurements. The main goal of this stage is to understand to what part of sky these frames are related.

With help of the improved method for the related frames identification the accuracy of astrometric reduction was increased in the CoLiTec software. The main purpose of this method is the special rule (uniform distribution) for the selection of reference stars in the frame (Figure 7).

Also, the accuracy of astrometric reduction as well as accuracy of moving objects detection was increased after using the newest stellar catalogs such as UCAC5 (Fedorov et al., 2018) and GAIA DR2 (Gaia Collaboration, 2016).

The photometric reduction includes the estimation of object's apparent brightness after its signal's amplitude. This stage is performed for all real objects in series of frames.

\section{Interframe processing methods}

Interframe processing is used to detect and estimate objects trajectories. The core of CoLiTec software consists of preliminary objects detection based on the accumulation of statistics that is proportional to the signals energy along possible object motion paths. Such accumulation is performed by multivalued transformation of the objects coordinates that is equivalent to the Hough space-time transformation (Savanevych et al., 2012).

CoLiTec software has abilities for detecting very slow, very fast objects, and objects with the near-zero apparent motion. Range of visible velocities of detected asteroids by CoLiTec software is from 0.7 to 40.0 pixels per frame. For example, the faster discovered NEO was K12C29D asteroid (40.0 pix./frame) as well as the slowest discovered object was ISON C/2012 S1 comet (0.8 pix./frame).

These possibilities are provided by the different computational methods that developed by authors and implemented in the CoLiTec software. One of them is a new iteration method for accurate estimation of asteroid coordinates, which is based on the subpixel Gaussian model of a discrete object image (Savanevych et. al., 2015). This model of the object image takes into account a prior form of the object image and consequently it is adapted more easily to any forms of real image. The method operates by continuous parameters (asteroid coordinates) in a discrete observational space (the set of pixels potentials) of the CCD-frame.

Full reliability of the detection of moving objects is retained up to the lower limit of SNR equal to 3 units in case of a minimum series consisting of four frames, with no stars covering of asteroid (Savanevych et al., 2015).

The detection of objects with the near-zero apparent motion is performed by the method, which is based on the significance verification of the speed factor of object (Khlamov et al., 2016). Fisher F-criterion is used as significance criterion in this method. It allows detection of objects that have a shift between frames, which isn't exceeded the object's image size by 3 RMS (Savanevych et al., 2018). For example, at the time of discovery, the image size of the comet C 2012 S1 (ISON) was five pixels and it has been shifted by three pixels for the four frames (Khlamov et al., 2017). The Centaur 2013 UL10 has been shifted by ten pixels with the image size of four pixels at the time of discovery.

The another method, which implemented in CoLiTec software, is the method for determining equatorial coordinates of celestial objects based on an assessment of their position in the digital frame (Pohorelov et al., 2016). Different reduction polynomial models (cubic and fifthpower) were implemented in this method. Also it allows assessing the significance of the reduction model coefficients and determining the influence of the polynomial model power on the accuracy of object's position assessment. This method also takes into account the peculiarities of astronomical reduction in long-focus and short-focus optical systems.

CoLiTec software equipped with the modern viewer of obtained results with a user-friendly GUI. LookSky runs independently of the main program and it can be used for independent review of CoLiTec processing results while the main program is processing data.

Also the system for monitoring processing messages with a detailed logging of handling process is implemented into CoLiTec software (Pohorelov et al., 2016). Enhanced control of input and output data is held at the each stage of processing. It allows detecting damaged data from the existed one.

\section{Conclusion}

The CoLiTec software is widely used in the different observatories in the world. It has been used in about 700000 observations, during which four comets $\mathrm{C} / 2011$ $\mathrm{X} 1$ (Elenin), P/2011 NO1 (Elenin), C/2012 S1 (ISON) and $\mathrm{P} / 2013$ V3 (Nevski) out of seven discovered in the CIS 
and the Baltic States over the past 20 years were identified using CoLiTec. In total, the CoLiTec software was used for discovery more than 1560 asteroids, including 5 NEO, 21 Trojan asteroids of Jupiter and 1 Centaur (see, also, Savanevych et al., 2012, 2015, 2018; Khlamov et al., 2016, 2017; Vavilova et al., 2012, 2017; Vavilova, 2016).

In 2014, the CoLiTec software was recommended to all members of the Gaia-FUN-SSO network for analyzing observations as a tool for detecting faint moving objects on CCD-frames (https://gaiafunsso.imcce.fr). Now we are working on the implementation of CoLiTec software into the GOTO project tasks.

\section{References}

Akhmetov V.S., Fedorov P.N., Velichko A.B., Shulga V.M.: 2017, MNRAS, 469, 763-773.

Dubovský P.A., Briukhovetskyi O.B., Khlamov S.V. et al.: 2017, OEJV, 180, 16.

Khlamov S.V. et al.: 2016. Eastern-European Journal of Enterprise Technologies, 80, 41-48.
Khlamov S., Savanevych V., Briukhovetskyi O., Pohorelov A.: 2017, Proceedings of the International Astronomical Union, 325, 349-352.

Gaia Collaboration: 2016, $A \& A, \mathbf{5 9 5}, \mathrm{A} 1,36$.

Fedorov P.N., Akhmetov V.S., Velichko A.B.: 2018, MNRAS, 476, 2743-2750.

Pohorelov A.V. et al.: 2016, Eastern-European Journal of Enterprise Technologies, 82, 42-49.

Pohorelov A.V., Khlamov S.V. et al.: 2016, Odessa Astron. Publ., 29, 136-140.

Savanevych V.E. et al.: 2012, Kosm. nauka tehnol., 18, 39-46.

Savanevych V.E., Briukhovetskyi O.B., Sokovikova N.S. et al.: 2015, MNRAS, 451, 3287-3298.

Savanevych V.E., Briukhovetskyi A.B., Ivashchenko Yu.N. et al.: 2015, Kinemat. Phys. Celest. Bodies, 31, 302-313.

Savanevych V.E., Khlamov S.V., Vavilova I.B. et al.: 2018, Astron. Astrophys., 609, A54, 11.

Vavilova I.B. et al.: 2012, Kinemat. Physics Celest. Bodies, 28, 85-102.

Vavilova I.B.: 2016, Odessa Astron. Publ., 29, 109-115.

Vavilova I.B. et al.: 2017, Proceedings of the International Astronomical Union, 325, 361-366. 